\title{
Evaluating the suitability of groundwater for drinking pur- poses in the North Chengdu Plain, China
}

\author{
Adam Khalifa Mohamed $^{1,2, *}$, Liu Dan $^{1}$, Song $\mathrm{Kai}^{1}$, Elsiddig Eldaw ${ }^{1,2}$, and Salma \\ Abualela $^{2}$ \\ ${ }^{1}$ Faculty of Geoscience and Environmental Engineering, Southwest Jiaotong University, China. \\ ${ }^{2}$ Faculty of Water and Environmental Engineering, Sudan University of Science and Technology, Sudan
}

\begin{abstract}
Groundwater is a significant and crucial component for all development activities of any life support system. In this study, the hydrochemical analysis and water quality index method (WQI) were used to assess groundwater quality for drinking purposes. Twelve groundwater samples were collected and analyzed into fourteen parameters which were considered as important indicators for assessing groundwater quality. A comparative study of these parameters with that of the Chinese Groundwater Standard (GB/T14848-2017) was conducted. It can be depicted from the results that groundwater quality is categorized as very hard, fresh water and slightly alkaline in nature. The major sequence of dominant cations and anions in groundwater are $\mathrm{Ca}^{2+}>\mathrm{Mg}^{2+}$ $>\mathrm{Na}^{+}>\mathrm{K}^{+}$and $\mathrm{HCO}_{3}^{-}>\mathrm{SO}_{4}^{2-}>\mathrm{Cl}^{-}$respectively. From the total 12 samples analyzed, the parameters of $\mathrm{TH}, \mathrm{NH}_{4}^{+}, \mathrm{Fe}$ and $\mathrm{Mn}$ of samples exceeded the limits set by (GB/T14848-2017) standard. Piper diagram illustrated that groundwater samples of the studied area are mostly of Ca-Mg- $-\mathrm{HCO}_{3}-\mathrm{SO}_{4}$ type. WQI showed all samples fall between excellent to good category of water and suitable for drinking purposes. The quality of groundwater is mainly affected from anthropogenic activities and natural influence. The proposed method is reliable and efficient for groundwater pollution assessment and can be used in decision-making.
\end{abstract}

\section{Introduction}

Groundwater is essential for providing water supplies to rural and urban communities in many countries of the world $[1,2]$. Nowadays, the contamination of groundwater is a major problem that has posed serious threats to human health and environmental values [3-6]. In the study area, the anthropogenic activities are deteriorating the water quality due to the disposal of domestic and industrial wastewater into rivers through the sewer systems and also extensive use of fertilizers, pesticides in agriculture [4,7]. These factors are representing the major role in causing the deterioration of groundwater quality through different chemical components, leading changes in the quality of the pumped water and suitability for human utilization. Therefore, assessing groundwater quality based on reliable assessment approach is very important for decision making.

*e-mail: adamkh124@yahoo.com 
The determinant of groundwater suitability for human use and irrigation is achieved through physical and chemical properties, as well as any altering factors that may have occurred because of human activity and microbial activities in soils [8, 9]. World Health Organization (WHO) and many countries have published the guidelines for drinking water. The measurement of the water quality parameters is necessary to compare with declared water quality standards in order to protect public health [10].

At present, numerous studies are available to evaluate the groundwater suitability for domestic use $[8,11]$. Most of these methods cannot clearly express the water pollutant categories [12]. However, hydrochemical analysis is very useful for analyzing a lot of practical problems respect with groundwater such as major ion chemistry, descriptive statistics techniques, etc [8]. Also, WQI is regarded as one of the most efficient technique to evaluate groundwater quality $[1,13]$. Among the main advantages of WQI is the ability to integrate data from multiple water quality parameters into a mathematical equation which determines the water quality level [14]. Therefore, the objective of this work is to assess the groundwater quality and to define its suitability for drinking based on hydrochemical analysis and WQI in the Quaternary Alluvial Basin.Thus, this serve as a background work to improve the evaluation of groundwater quality in the planning of water resources in the future.

\section{Study region}

The study area is located in the North Chengdu Plain, China. This area comprises of many villages with a population of 140,000 . It is bounded between latitudes $30^{\circ} 40^{\prime} 40^{\prime \prime}$ to $30^{\circ} 57^{\prime} 58^{\prime \prime}$, and longitudes $103^{\circ} 54^{\prime} 02^{\prime \prime}$ to $104^{\circ} 16^{\prime} 54^{\prime \prime}$ and covers about $18.077 \mathrm{Km}^{2}$. The area is bordered by several river bodies, which shoot off from the Minjiang river. The climate in this region is sub-humid monsoon (Figure. 1). The monthly average of cold and hot temperature is $4.6^{\circ} \mathrm{C}$ and $24.4^{\circ} \mathrm{C}$, respectively with annual mean value of $10.4^{\circ} \mathrm{C}$. Annual rainfall in this region is about $1134.8 \mathrm{~mm}$ and it is the major source of recharging the groundwater. The aquifer of this study area is part of the North Chengdu Alluvial Plain and is underlain by alluvial deposits of Quaternary Unconsolidated Sediments. It has an elevation that ranges between 450 to $750 \mathrm{~m}$ above sea level. The overall terrain is tilting from Northwest to Southeast, with the average gradient of 3 to $10 \%$. The aquifer in this area is primarily composed of Quaternary cobbles, gravel, sand, and laminated or lensed clay with a shallow depth of the groundwater level (2.0 to $10 \mathrm{~m}$ ). Groundwater from the Quaternary Unconsolidated Sediments is the primary source of drinking water, irrigation and industrial use. This Basin is susceptible to contamination from various human activities due to high hydraulic conductivity which is estimated about $\mathrm{k}=10$ to $50 \mathrm{~m} /$ day and shallow depth of the groundwater. In the study area, there is the LongQiao water plant which was established at $38 \mathrm{~m}$ from the Pi River. The yield capacity of this plant is about 10000 to $12000 \mathrm{~m}^{3} / \mathrm{d}$, while the amount of water supply for distribution systems is 8000 to $10000 \mathrm{~m}^{3} / \mathrm{d}$.

\section{Materials and Method}

\subsection{Sampling Procedure}

In this work, groundwater samples were collected from 12 locations (Figure. 1), and analyzed for various parameters such as $\left(\mathrm{pH}, \mathrm{TH}, \mathrm{TDS}, \mathrm{Na}^{+}, \mathrm{K}^{+}, \mathrm{Ca}^{2+}, \mathrm{Mg}^{2+}, \mathrm{HCO}_{3}^{-}, \mathrm{Cl}^{-}, \mathrm{SO}_{4}^{2-}, \mathrm{NO}_{3}^{-}\right.$, $\mathrm{NH}_{4}^{+}, \mathrm{Fe}$ and $\mathrm{Mn}$ ). It is worth mentioning, a comprehensive field survey was conducted in the study area and it was observed that the location of wells is exposed to the risk of groundwater pollution. Therefore, these samples were selected because they are relative importance in the study area as a source of drinking water. Instantaneously after taking samples, TDS 

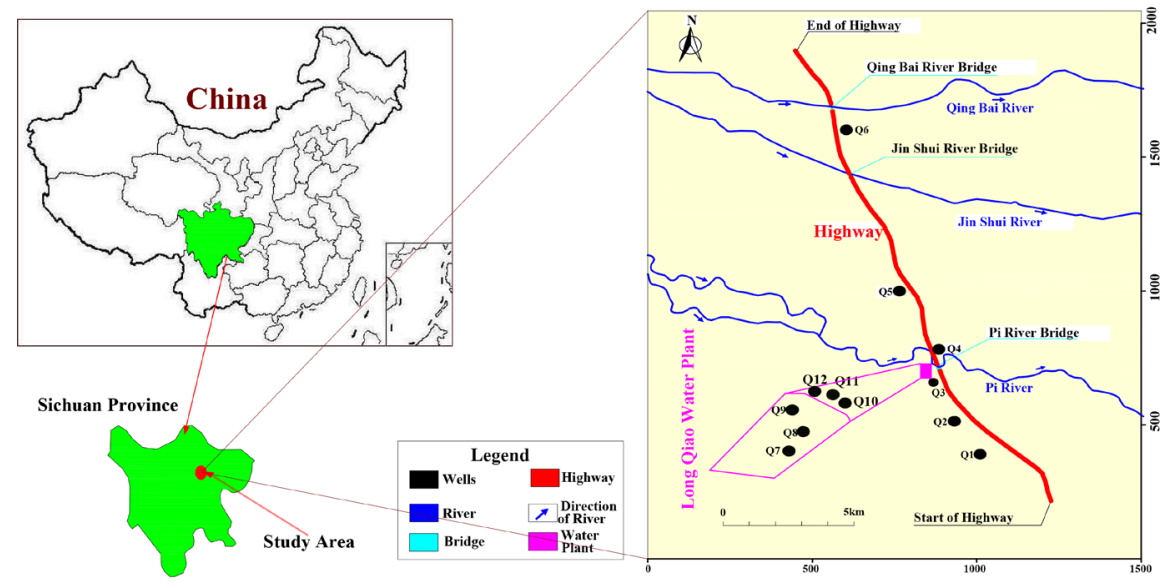

Figure 1: Site map of the study region for sampling locations.

and $\mathrm{pH}$ values were taken in-situ because it may change during transport. Then, samples were delivered to the laboratory on the same day during October 2017. Flame photometer is employed to analyze the concentrations of $\mathrm{Na}^{+}$and $\mathrm{K}^{+}$and volumetric methods was used to analyze $\mathrm{TH}, \mathrm{Ca}^{2+}, \mathrm{Mg}^{2+}, \mathrm{HCO}_{3}^{-}$and $\mathrm{Cl}^{-}$. The anion $\mathrm{SO}_{4}^{2-}, \mathrm{NO}_{3}^{-}, \mathrm{NH}_{4}^{+}$and heavy metals (Fe and $\mathrm{Mn}$ ) were measured using a spectrophotometer. All physicochemical parameters are expressed in $\mathrm{mg} / \mathrm{L}$ excluding hydrogen ion $(\mathrm{pH})$. The hydrochemical facies (Piper diagram) in the study area was plotted for studying the groundwater quality in detail. The Chinese national standard for groundwater (GB/T 14848-2017) was used to evaluated groundwater suitability for drinking, domestic purposes of various water quality parameters.

\subsection{Water quality index method (WQI)}

WQI is calculated based on many physicochemical parameters of groundwater chemistry [14]. The calculations are done according to the standards set by (GB/T 14848-2017) and (WHO 2011). The (GB/T 14848-2017) standard of China was used as main criterion for evaluation, while the (WHO 2011) was applied in the case there are no limits set by the Chinese standard for parameters. In this study, three steps were obeyed for computing WQI [13]. Firstly, each of the fourteen parameters ( $\mathrm{pH}, \mathrm{TH}, \mathrm{TDS}, \mathrm{Na}^{+}, \mathrm{K}^{+}, \mathrm{Ca}^{2+}, \mathrm{Mg}^{2+}, \mathrm{HCO}_{3}^{-}$, $\mathrm{Cl}^{-}, \mathrm{SO}_{4}^{2-}, \mathrm{NO}_{3}^{-}, \mathrm{NH}_{4}^{+}, \mathrm{Fe}$ and $\mathrm{Mn}$ ) is assigned a weight (wi)depending on its comparative significance in general water quality. The allotted weight ranges between 1 to 5 . The highest weight of five has been given to parameters TDS, $\mathrm{SO}_{4}^{2-}, \mathrm{NO}_{3}^{-}$and $\mathrm{NH}_{4}^{+}$because to their major importance in water quality assessment [15]. The least weight of 1 assigned for $\mathrm{HCO}_{3}^{-}$ because it does not play relevant part in the assessment of water quality. The remaining parameters were assigned a value between 1 to 5 depending on their importance in the whole quality of water for drinking purposes. [14, 15]. Secondly, the computation of the relative weight (Wi) is given in equation below (1):

$$
W_{i}=\frac{w_{i}}{\sum_{n}^{i-1} w_{i}}
$$

where the relative weight is represented by $W_{i}, w_{i}$ indicates the individual parameter weight, $n$ represents number of groundwater parameters. Thirdly, the computation of quality ranking 
$q_{i}$ for each physiochemical parameter is done through division of its concentration in every water sample with respect to its respective standards suggested by (GB/T 14848-2017) and (WHO 2011). The result obtained is multiplied by 100 using equation (2):

$$
q_{i}=\frac{C_{i}}{S_{i}} x 100
$$

where $q_{i}$ represents the quality rating, $C_{i}$ indicates the concentration of each groundwater parameter in every sample $(\mathrm{mg} / \mathrm{L})$, and $S_{i}$ is Chinese groundwater quality standard for each physicochemical parameter in $(\mathrm{mg} / \mathrm{L})$ based on the Chines national quality standard $(\mathrm{GB} / \mathrm{T}$ 14848-2017) for groundwater. For computing the WQI, the sub-index of water quality (SI) for each physicochemical parameter is determined as per the expressions in $(3,4)$ :

$$
\begin{gathered}
S I_{i}=W_{i} \times q_{i} \\
W Q I=\sum_{i=1}^{n} S I_{i}
\end{gathered}
$$

The standard rating of water quality according to WQI scale is $<50$ signify excellent; 50 to 100 is good; 100 to 200 is poor; 200 to 300 is very poor and $>300$ is unfit for drinking water.

\section{Results and Discussion}

\subsection{Physicochemical properties of groundwater}

Statistics of the groundwater quality parameters is presented in Table 1. The groundwater is slightly alkaline in the study region with an average $\mathrm{pH}$ of 7.47. All samples of $\mathrm{pH}$ are found within the permissible limit of (GB/T 14848-2017) standard. The total hardness concentration ranges between 221 to $700 \mathrm{mg} / \mathrm{L}$ with a mean concentration value of $368.5 \mathrm{mg} / \mathrm{L}$. The TDS concentration of the study area varies from 295 to $943 \mathrm{mg} / \mathrm{L}$ with a mean value $479.2 \mathrm{mg} / \mathrm{L}$. All TH and TDS samples are within the acceptable limit of 450 to $1000 \mathrm{mg} / \mathrm{L}$ respectively, recommended by the (GB/T 14848-2017) standard except sample Q2 of TH exceeded the permissible according to the standard of (GB/T 14848-2017). The increase of TH ion within the study area is basically attributed due to the various anthropogenic activities and leaching of $\mathrm{Ca}^{2+}$ and $\mathrm{Mg}^{2+}$ ions into groundwater. According to $[16,17]$, the groundwater quality of all samples is categorized into fresh water (TDS) and very hard (TH). The concentration of $\mathrm{Na}^{+}$ion ranges between 9.9 to $24.3 \mathrm{mg} / \mathrm{L}$, with an average value of $13.8 \mathrm{mg} / \mathrm{L}$. This ion is found below the acceptable limit of (GB/T 14848-2017) standard. Whereas, the average value concentrations of $\mathrm{K}^{+}, \mathrm{Ca}^{2+}, \mathrm{Mg}^{2+}$ and $\mathrm{HCO}_{3}^{-}$were 2.6, 109.618 .9 , and $306.4 \mathrm{mg} / \mathrm{L}$ respectively. It is worth mentioned, no threshold set for the latter parameters have so far been stated for the standard of groundwater quality. The $\mathrm{Cl}^{-}, \mathrm{SO}_{4}^{2-}$ and $\mathrm{NO}_{3}^{-}$concentrations in the study area observed from 10.2 to $66.5,34.9$ to 164 and 0.21 to $7.01 \mathrm{mg} / \mathrm{L}$ with an average $23.7,70.8$ and $2.23 \mathrm{mg} / \mathrm{L}$ respectively. The present study reveals that all sampling sites fall under the allowed limit of (GB/T 14848-2017) standard. The $\mathrm{NH}_{4}^{+}$content is in the range of 0.04 to $0.57 \mathrm{mg} / \mathrm{L}$ with a mean value of $0.18 \mathrm{mg} / \mathrm{L}$. In all groundwater samples, only sample Q8 exceeding the allowable limit of the standard and other samples are found within the (GB/T 14848-2017) standard of $0.5 \mathrm{mg} / \mathrm{L}$. The higher value of $\mathrm{NH}_{4}^{+}$of well Q8 is mainly due to the natural decomposition of organic matter from sewage and industrial water, and also this well is sited close to the septic tank belonging to the plant workers. In the study area, $\mathrm{Fe}$ and $\mathrm{Mn}$ are obtained in the range from 0.1 to 1.15 and 0.001 to $0.34 \mathrm{mg} / \mathrm{L}$ with the average 0.47 and $0.08 \mathrm{mg} / \mathrm{L}$ respectively. From the samples analyzed, $41.3 \%$ of the total groundwater 
Table 1: Statistical summary of water parameters against (GB/T 14848-2017) standard

\begin{tabular}{|c|c|c|c|c|c|c|c|c|c|c|c|c|c|c|}
\hline \multirow{2}{*}{ Statistical parameters } & \multicolumn{14}{|c|}{ Parameters } \\
\hline & $\mathrm{PH}$ & $\mathrm{TH}$ & TDS & $\mathrm{Na}$ & $\mathrm{K}$ & $\mathrm{Ca}$ & $\mathrm{Mg}$ & $\mathrm{HCO}_{3}$ & $\mathrm{Cl}$ & $\mathrm{SO}_{4}$ & $\mathrm{NO}_{3}$ & $\mathrm{NH}_{4}$ & $\mathrm{Fe}$ & $\mathrm{Mn}$ \\
\hline Min & 6.97 & 221 & 295 & 9.9 & 1.5 & 78.2 & 12 & 219 & 10.2 & 34.9 & 0.21 & 0.04 & 0.10 & 0.001 \\
\hline $\operatorname{Max}$ & 7.74 & 700 & 943 & 24.3 & 5.2 & 193 & 35 & 414 & 66.5 & 164 & 7.01 & 0.57 & 1.15 & 0.34 \\
\hline Mean & 7.47 & 368.5 & 479.2 & 13.8 & 2.6 & 109.6 & 18.9 & 306.4 & 23.7 & 70.8 & 2.23 & 0.18 & 0.47 & 0.08 \\
\hline Standard deviation & 0.19 & 120 & 170.8 & 4.95 & 1.3 & 30.0 & 5.7 & 63.5 & 14.9 & 31.3 & 2.12 & 0.14 & 0.33 & 0.10 \\
\hline (GB/T 14848-2017) & $6.5-8.5$ & 450 & 1000 & 200 & - & - & - & - & 250 & 250 & 20 & 0.5 & 0.3 & 0.1 \\
\hline
\end{tabular}

Table 2: Weight and relative weight of each parameter used for WQI determination

\begin{tabular}{|c|c|c|c|c|c|c|c|c|c|c|c|c|c|c|c|}
\hline & \multicolumn{14}{|c|}{ Parameters } & \\
\hline & PH & $\mathrm{TH}$ & TDS & $\mathrm{Na}$ & $\mathrm{K}$ & $\mathrm{Ca}$ & $\mathrm{Mg}$ & $\mathrm{HCO}_{3}$ & $\mathrm{Cl}$ & $\mathrm{SO}_{4}$ & $\mathrm{NO}_{3}$ & $\mathrm{NH}_{4}$ & $\mathrm{Fe}$ & $\mathrm{Mn}$ & \\
\hline (GB/T 14848-2017) & $6.5-8.5$ & 450 & 1000 & 200 & - & - & - & - & 250 & 250 & 20 & 0.5 & 0.3 & 0.1 & \\
\hline WHO (2011) & $6.5-8.5$ & 300 & 500 & 200 & 12 & 75 & 50 & 500 & 250 & 250 & 50 & 35 & 0.3 & 0.1 & \\
\hline Weight (wi) & 4 & 3 & 5 & 2 & 2 & 4 & 2 & 1 & 5 & 5 & 5 & 5 & 4 & 4 & $\sum w_{i}=51$ \\
\hline $\begin{array}{l}\text { Relative weight } \\
\qquad W_{i}=\frac{w_{i}}{\sum_{i-1}^{n} w}\end{array}$ & 0.078 & 0.059 & 0.098 & 0.039 & 0.039 & 0.078 & 0.039 & 0.02 & 0.098 & 0.098 & 0.098 & 0.098 & 0.078 & 0.078 & $\sum_{i-1}^{n} w_{i}=1$ \\
\hline
\end{tabular}

Table 3: Classification of Water quality index (WQI) for individual samples

\begin{tabular}{|c|c|c|c|c|c|c|c|c|c|c|c|c|}
\hline \multicolumn{13}{|c|}{ Name of well } \\
\hline & Q1 & Q2 & Q3 & Q4 & Q5 & Q6 & Q7 & Q8 & Q9 & Q10 & Q11 & Q12 \\
\hline WQI values & 57.859 & 70.955 & 50.489 & 60.382 & 46.628 & 41.886 & 41.154 & 85.178 & 36.653 & 51.557 & 57.601 & 58.128 \\
\hline $\begin{array}{l}\text { Classification } \\
\text { type }\end{array}$ & $\begin{array}{l}\text { Good } \\
\text { water }\end{array}$ & $\begin{array}{l}\text { Good } \\
\text { water }\end{array}$ & $\begin{array}{l}\text { Good } \\
\text { water }\end{array}$ & $\begin{array}{l}\text { Good } \\
\text { water }\end{array}$ & $\begin{array}{l}\text { Excellent } \\
\text { water }\end{array}$ & $\begin{array}{l}\text { Excellent } \\
\text { water }\end{array}$ & $\begin{array}{l}\text { Excellent } \\
\text { water }\end{array}$ & $\begin{array}{l}\text { Good } \\
\text { water }\end{array}$ & $\begin{array}{l}\text { Excellent } \\
\text { water }\end{array}$ & $\begin{array}{l}\text { Good } \\
\text { water }\end{array}$ & $\begin{array}{l}\text { Good } \\
\text { water }\end{array}$ & $\begin{array}{l}\text { Good } \\
\text { water }\end{array}$ \\
\hline
\end{tabular}

samples of $\mathrm{Fe}$ are found within acceptable limit according to Chinese standard, represented in the sampling sites (Q2, Q5, Q6, Q7, and Q9), and the others exceeded the permissible limit. Also, all groundwater samples of $\mathrm{Mn}$ is found to be less than the permissible limit set by (GB/T 14848-2017), except samples, Q3 and Q8 exceeded the permissible limit. The high concentration of $\mathrm{Fe}$ and $\mathrm{Mn}$ in the Basin Quaternary Unconsolidated Sedimentary, in general caused by geological environment conditions [4]. Thus, it is considered natural.

From the above discussion to this points, the water quality assessment findings show that the main indicators exceeding Class III in the study area were $\mathrm{TH}, \mathrm{NH}_{4}^{+}, \mathrm{Fe}$ and $\mathrm{Mn}$ for seven sampling sites comprised $58.3 \%$. After investigation of the area, the increase of these parameters could be attributed to several reasons. 1. It was observed the sampling sites are more susceptible to contamination resulting from inappropriate use of agricultural inputs, open defecation and many more which comes from human activities. These activities result in damage to public water supplies as LongQiao water plant and ather sampling sites 2. The area is bordered by several rivers, which originate from Minjiang river. These rivers have all become wastewater drains for many sewer system and industrial waste of nearby factories which greatly affected the quality of groundwater due to the shallow water depth of the aquifer in this area. 3. The study area is the center for several industries and some different enterprises which are concentrated on the both sides of highway. These facilities are one of the main factors influencing the quality of groundwater this area.

\subsection{Hydrochemical types}

Piper trilinear diagram for anions and cations were plotted to describe the hydrochemical types [18] as it is clearly useful in bringing out chemical relationships in a set of ground- 
water samples in terms of dissolved constituents [19].In this study, the diagram is made up of two triangular, including a central diamond-shaped fields (Figure. 2). In the triangular fields, proportion measures of major cations $\left(\mathrm{Ca}^{2+}>\mathrm{Mg}^{2+}>\mathrm{Na}^{+}>\mathrm{K}^{+}\right)$and $\left(\mathrm{HCO}_{3}^{-}>\mathrm{SO}_{4}^{2-}\right.$ $>\mathrm{Cl}^{-}$) are drown individually and further projected onto the central field to represent the entire features of water [13]. From the Piper diagram results, three hydrochemistry types are represented in the study area as follows: sites Q1, Q2, Q5, Q6, Q7 and Q9 are the Ca-Mg$\mathrm{HCO}_{3}-\mathrm{SO}_{4}$; sites Q3, Q8, Q11 and Q12 are the $\mathrm{Ca}-\mathrm{HCO}_{3}$ type, and sites Q4 and Q10 are the $\mathrm{Ca}-\mathrm{Mg}-\mathrm{HCO}_{3}$ type. The percentage of these three hydrochemical types were $50 \%, 33.3 \%$, and $16.7 \%$ respectively. This result delineates that the hydrochemical facies of groundwater is mostly Ca-Mg-HCO3-SO ${ }_{4}$. The main cations and anions in water are $\mathrm{Ca}^{2+}>\mathrm{Mg}^{2+}>$ $\mathrm{Na}^{+}>\mathrm{K}^{+}$and $\mathrm{HCO}_{3}^{-}>\mathrm{SO}_{4}^{2-}>\mathrm{Cl}^{-}$respectively. In groundwater, the anions and cations could come mainly from human activities such as the application of fertilizers and pesticides uncontrolled groundwater development and from the dissolution of carbonate rock [20].

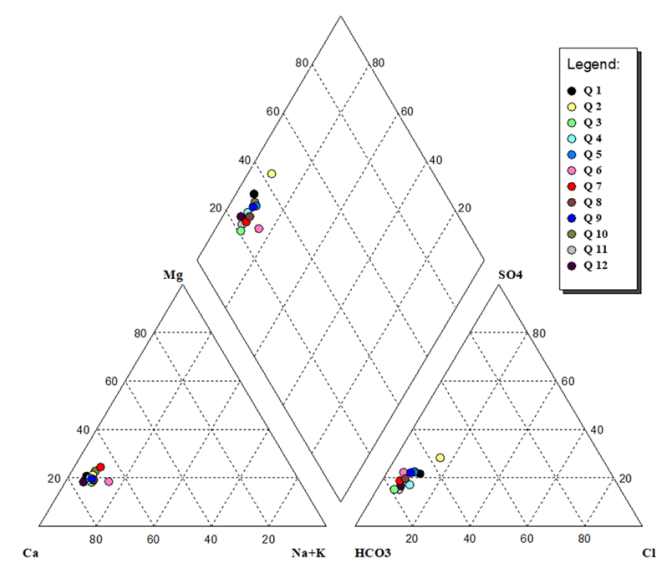

Figure 2: Piper trilinear diagram of groundwater chemistry in the study region.

\subsection{Water quality index evaluation (WQI)}

In this paper, WQI has been used as a technique to outlook water quality for drinking purposes. The weight $\mathrm{Wi}$ and relative weight wi were calculated for water quality parameters used for WQI determination as shown in Table 2. The computed WQI extended from 36.653 to 85.178 . By the computed WQI values, $33.3 \%$ and $66.7 \%$ of the groundwater samples are grouped as excellent and good water respectively (Table 3 ) according to the classification ranges for WQI. In this study, water quality index (WQI) reveals that all groundwater samples are found under between excellent and good category of water and appropriate for drinking purposes. Therefore, this method is reliable and efficient for groundwater pollution assessment and can be used in decision-making.

\section{Conclusions}

In the present study, the hydrochemical result shows that the groundwater in our research area as slightly alkaline, very hard and fresh in nature of $\mathrm{pH}, \mathrm{TH}$ and TDS respectively. Groundwater portability was appraised using (GB/T 14848-2017) standard. The results analysis revealed that most of the groundwater parameters were found within the allowable limits 
except some parameters in some samples of groundwater like ( $\mathrm{TH}, \mathrm{NH}_{4}^{+}, \mathrm{Fe}$ and $\mathrm{Mn}$ ), which exceeded the permissible limits. The major sequence of dominant cations and anions in the groundwater are $\mathrm{Ca}^{2+}>\mathrm{Mg}^{2+}>\mathrm{Na}^{+}>\mathrm{K}^{+}$and $\mathrm{HCO}_{3}^{-}>\mathrm{SO}_{4}^{2-}>\mathrm{Cl}^{-}$respectively. Piper's trilinear diagram indicates that the dominant hydrochemical facies of groundwater in the study are $\mathrm{Ca}-\mathrm{Mg}-\mathrm{HCO}_{3}, \mathrm{Ca}-\mathrm{Mg}-\mathrm{HCO}_{3}-\mathrm{SO}_{4}$, and $\mathrm{Ca}-\mathrm{HCO}_{3}-\mathrm{SO}_{4}$ types and representing $58.3 \%$, $25 \%$ and $16.7 \%$ respectively for all the sampling sites.

The WQI was applied to estimate the groundwater quality and its portability to drinking usage. Owing to results of the WQI, $33.3 \%$ of groundwater samples denote "excellent water", $66.7 \%$ show "good water". This result reveals that the samples in all wells are suitable for drinking. The main pollution sources responsible for variation in groundwater quality come from industrial effluents, domestic and agricultural runoff through anthropogenic processes and natural influence. The study, therefore, recommends the need for regular monitoring of groundwater levels and adopting appropriate measures to overcome pollution and facilitate sustainable groundwater quality of the basin.

\section{References}

1. N. Adimalla, P. Li, and S. Venkatayogi, "Hydrogeochemical Evaluation of Groundwater Quality for Drinking and Irrigation Purposes and Integrated Interpretation with Water Quality Index Studies," Environmental Processes, vol. 5, pp. 363-383, (2018).

2. N. Adimalla, S. K. Vasa, and P. Li, "Evaluation of groundwater quality, Peddavagu in Central Telangana (PCT), South India: an insight of controlling factors of fluoride enrichment," Modeling Earth Systems and Environment, vol. 4, pp. 841-852, (2018).

3. N. Adimalla, P. Li, and H. Qian, "Evaluation of groundwater contamination for fluoride and nitrate in semi-arid region of Nirmal Province, South India: A special emphasis on human health risk assessment (HHRA)," Human and Ecological Risk Assessment: An International Journal, pp. 1-18, (2018).

4. A. K. Mohamed, D. Liu, M. A. Mohamed, and K. Song, "Groundwater quality assessment of the quaternary unconsolidated sedimentary basin near the Pi river using fuzzy evaluation technique," Applied Water Science, vol. 8, p. 65, (2018).

5. N. Adimalla and P. Li, "Occurrence, health risks, and geochemical mechanisms of fluoride and nitrate in groundwater of the rock-dominant semi-arid region, Telangana State, India," Human and Ecological Risk Assessment: An International Journal, pp. 1-23, (2018).

6. A. Narsimha and S. Rajitha, "Spatial distribution and seasonal variation in fluoride enrichment in groundwater and its associated human health risk assessment in Telangana State, South India," Human and Ecological Risk Assessment: An International Journal, pp. 1-14, (2018).

7. A. Kareem, O. Mustafa, and B. Merkel, "Geochemical and environmental investigation of the water resources of the Tanjero area, Kurdistan region, Iraq," Arabian Journal of Geosciences, vol. 11, p. 461, (2018).

8. B. Agoubi, A. Kharroubi, and H. Abida, "Hydrochemistry of groundwater and its assessment for irrigation purpose in coastal Jeffara Aquifer, southeastern Tunisia," Arabian Journal of Geosciences, vol. 6, pp. 1163-1172, (2013).

9. N. Adimalla, "Groundwater Quality for Drinking and Irrigation Purposes and Potential Health Risks Assessment: A Case Study from Semi-Arid Region of South India," Exposure and Health, pp. 1-15, (2018).

10. A. Qishlaqi, S. Kordian, and A. Parsaie, "Hydrochemical evaluation of river water quality—a case study," Applied Water Science, vol. 7, pp. 2337-2342, (2017). 
11. B. Agoubi, F. Souid, A. Kharroubi, and A. Abdallaoui, "Assessment of hot groundwater in an arid area in Tunisia using geochemical and fuzzy logic approaches," Environmental Earth Sciences, vol. 75, p. 1497, (2016).

12. Z. Li, B. Zhou, D. Teng, W. Yang, and D. Qiu, "Comprehensive evaluation method of groundwater environment in a mining area based on fuzzy set theory," Geosystem Engineering, pp. 1-10, (2017).

13. S. Varol and A. Davraz, "Evaluation of the groundwater quality with WQI (Water Quality Index) and multivariate analysis: a case study of the Tefenni plain (Burdur/Turkey)," Environmental Earth Sciences, vol. 73, pp. 1725-1744, (2014).

14. A. Bouderbala, B. Remini, A. Saaed Hamoudi, and A. Pulido-Bosch, "Assessment of groundwater vulnerability and quality in coastal aquifers: a case study (Tipaza, North Algeria)," Arabian Journal of Geosciences, vol. 9, (2016).

15. T. K. Boateng, F. Opoku, S. O. Acquaah, and O. Akoto, "Groundwater quality assessment using statistical approach and water quality index in Ejisu-Juaben Municipality, Ghana," Environmental Earth Sciences, vol. 75, pp. 1-14, (2016).

16. D. Todd, "Groundwater hydrology (p. 535)," New York: Jon Wiley \& Sons Inc, (1980).

17. D. C. N. Sawyer and P. L. McCarty, "Chemistry for sanitary engineers," in Chemistry for sanitary engineers, ed: McGraw-Hill, (1967).

18. A. M. Piper, "A graphic procedure in the geochemical interpretation of water-analyses," Eos, Transactions American Geophysical Union, vol. 25, pp. 914-928, (1944).

19. W. C. Walton, Groundwater resource evaluation vol. 664: McGraw-Hill New York, (1970).

20. I. Jasmin and P. Mallikarjuna, "Physicochemical quality evaluation of groundwater and development of drinking water quality index for Araniar River Basin, Tamil Nadu, India," Environmental monitoring and assessment, vol. 186, pp. 935-948, (2014). 